This item was submitted to Loughborough's Research Repository by the author.

Items in Figshare are protected by copyright, with all rights reserved, unless otherwise indicated.

\title{
Regulating for e-waste in China: progress and challenges
}

PLEASE CITE THE PUBLISHED VERSION

http://dx.doi.org/ 10.1680/muen.2009.162.2.79

PUBLISHER

(c) ICE Publishing Ltd.

VERSION

VoR (Version of Record)

LICENCE

CC BY-NC-ND 4.0

REPOSITORY RECORD

Ye, Jing, Sam Kayaga, and lan K. Smout. 2019. "Regulating for E-waste in China: Progress and Challenges". figshare. https://hdl.handle.net/2134/10031. 
This item was submitted to Loughborough's Institutional Repository (https://dspace.lboro.ac.uk/) by the author and is made available under the following Creative Commons Licence conditions.

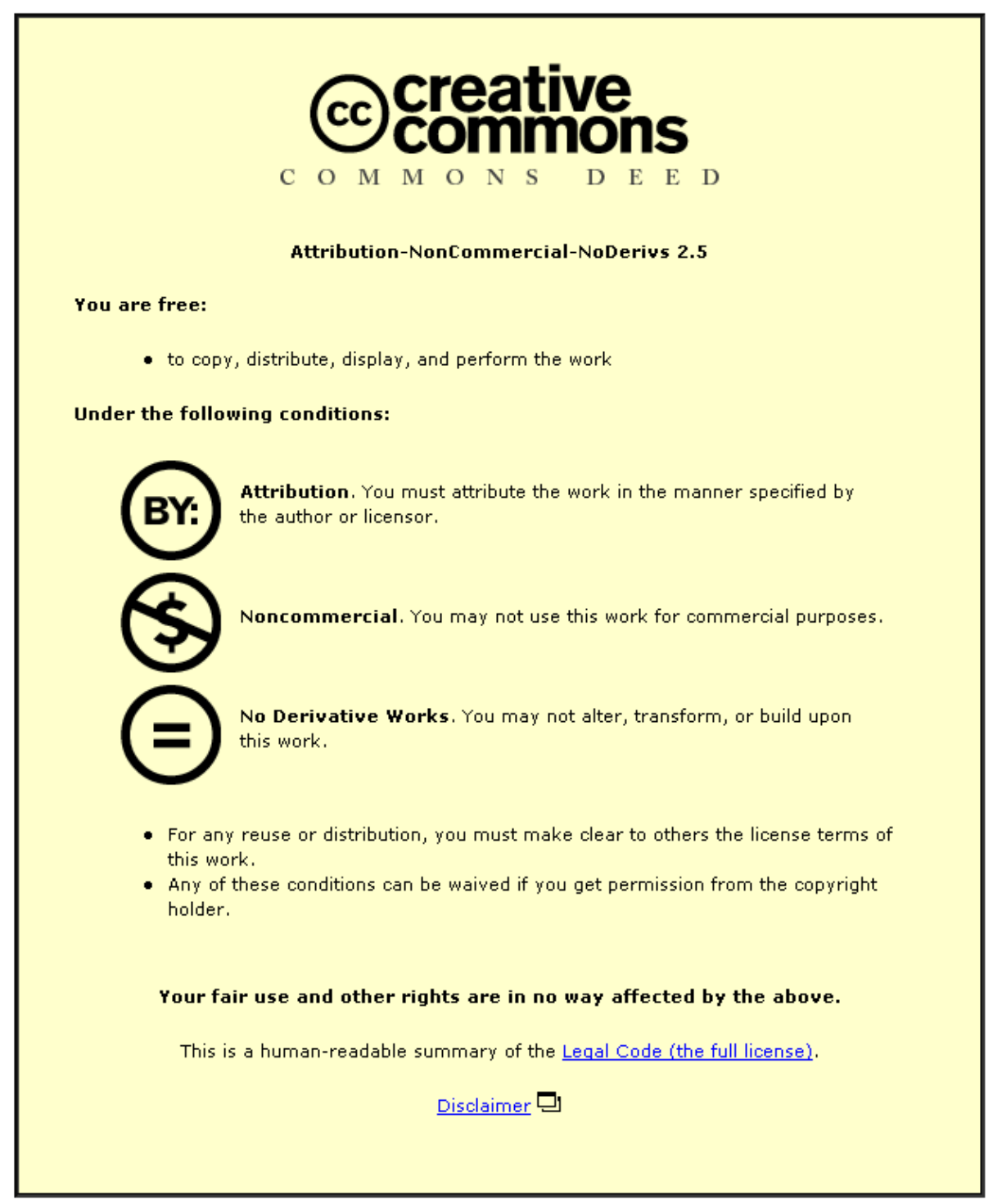

For the full text of this licence, please go to: http://creativecommons.org/licenses/by-nc-nd/2.5/ 


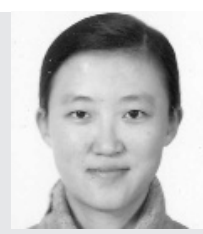

Jing Ye

PhD candidate, Department of Civil and Building Engineering Loughborough University, Leicestershire, UK

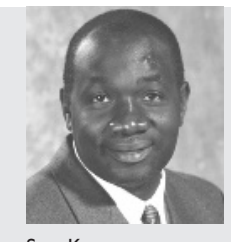

Sam Kayaga Programme Manager, Water, Engineering and Development Centre, Loughborough University, Leicestershire, UK

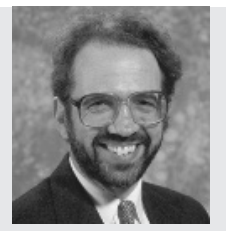

lan Smout

Director, Water, Engineering

and Development Centre,

Loughborough University,

Leicestershire, UK

\section{Regulating for e-waste in China: progress and challenges}

J. Ye MSc, PhD, S. Kayaga MSc(Eng), MSc(DevMgmt), PhD, CEng, MCIWEM and I. Smout MSc, CEng, FICE, MIAgrE, MCIWEM

Electronic waste (e-waste) is an emerging issue in the municipal towns of China. Its significance is driven by the rapidly increasing quantities, the hazards involved and the valuable materials in it. The poor quality e-waste recycling and disposal methods commonly practised in China have serious and hazardous effects on the environment and on the health of workers and residents. Additionally, industrialised countries are exporting increasing quantities of e-waste to China, complicating the situation further. The Chinese government needs to strengthen regulatory systems to ensure that the huge economic benefits from the e-waste recycling industry are not overshadowed by the negative impact on welfare and overall environmental sustainability. In response to the growing concern on e-waste, the government and other policy-making agencies in China are continuously strengthening the legislative and institutional framework for regulating importation and industrial activities in e-waste recycling and disposal. This paper provides a situational analysis and discusses the basic elements of the existing legislative framework for e-waste management in China. The paper concludes with an analysis of opportunities and challenges that exist in improving the enabling/regulatory environment for a hazardous but valuable commodity in a fastgrowing economy.

\section{INTRODUCTION}

During the last two decades, technological advances in electronic data management and communications have spurred economic growth and improved people's lives in countless ways in different parts of the world. However, the rapid growth of the electronics industry and the growing dependence on electronic products both at home and in the work place has given rise to a new environmental challenge: electronic waste (e-waste). E-waste has been the most rapidly growing solid waste problem in the world. It was estimated in 2000 that the volume of ewaste was rising by 3-5\% per year, almost three times faster than the municipal solid waste stream. ${ }^{1}$ For instance, it was estimated that approximately 20 million portable computers (PCs) became obsolete throughout the world in 1994. Ten years later the number was estimated at over 100 million, making a cumulative total of 500 million between 1994 and 2003. ${ }^{2}$ Similarly, about 130 million cell phones were discarded (equivalent to $65000 \mathrm{t}$ of e-waste) by $2005 .^{3}$ Examples of other portable electronic devices generating high quantities of e-waste are personal digital assistants (PDAs), MP3 players, computer games and other peripherals.

E-waste has typically affected the waste stream in a noticeable manner through the successive addition of new kinds of waste and has further complicated the problems associated with solid waste management. Besides the large quantity, another issue of concern is that e-waste contains over 1000 different substances, many of which are toxic, such as lead on circuit boards, lead oxide and cadmium in monitor cathode ray tubes (CRTs), mercury in switches and sensors, cadmium in computer batteries, polychlorinated biphenyls (PCBs) in older capacitors and transformers and brominated flame retardants in printed circuit boards, plastic casings, cables and polyvinyl chloride (PVC) cable insulation. Due to the hazards involved, disposing and recycling e-waste has serious health, environmental and legal implications. If disposed improperly, e-waste will result in serious environmental pollution. When it is land-filled or incinerated, it poses significant contamination problems. Landfills leach toxins into groundwater and incinerators emit toxic air pollutants including dioxins and furans.

Additionally, e-waste has a high residual value. If recycled properly, some of the components in it can be used to replace raw materials and components required in the growing electronic industry and other manufacturing fields. Many valuable materials in e-waste, such as gold, platinum, cadmium and barium have a high economic value and could be recycled by proper technologies. Environmentally sound recycling of e-waste therefore has the potential to reap high economic returns. E-waste recycling and disposal also can play an important role in the comprehensive utilisation of resources.

The level of generation of e-waste in developing countries is lower than in industrialised countries and little reliable data are available. However, the increased accumulation of e-waste in the former cannot be ignored. In the first instance, e-waste has also become the fastest growing waste stream in some developing countries. In India alone, it was estimated in 2003 that about 1.38 million PCs per year were discarded from the business sector and individual households, while $1050 \mathrm{t}$ of e-waste are produced by manufacturers/assemblers annually. ${ }^{4}$ Second, due to inadequate professional capacity and lack of environmentally sound technologies to dispose/recycle e-waste, the processes utilised in developing countries such as China, India and Pakistan are relatively primitive and extremely 
polluting. In some small-scale e-waste dismantling factories and household work-sheds, workers use simple and even primitive methods to dispose of e-waste which are extremely polluting and harmful to the health of workers and residents. ${ }^{5}$ For instance, preliminary investigations in Pakistan revealed that circuit boards are being de-soldered using blow torches, with no ventilation fans, in the same way as acid operations take place in enclosed premises with inadequate ventilation. ${ }^{5}$ In India, open burning of circuit boards in the middle of New Delhi neighbourhoods is routine, as is the use of child labour to accomplish these tasks. ${ }^{6}$

On the other hand, industrialised countries export e-waste to the developing countries, in the name of donations, reuse or recycling. This is an indirect way of dumping hazardous e-waste in these countries. ${ }^{5}$ Such 'exports' have aggravated the e-waste problem in developing countries. As well as handling their own rapidly growing e-waste, developing countries now also have to manage the e-waste being dumped within their national boundaries by industrialised countries. This has grown to the extent that e-waste management is becoming a critical issue in some developing countries, such as China, India and Pakistan. This paper, which is based on a $\mathrm{PhD}$ study, ${ }^{7}$ provides a situational analysis and discusses the basic elements of the existing legislative framework for e-waste management in China. The paper concludes with an analysis of opportunities and challenges that exist to improving the enabling/regulatory environment for a hazardous but valuable commodity in a fastgrowing economy.

\section{MAGNITUDE AND FLOW OF E-WASTE IN CHINA}

The electronic industry has become one of the most rapidly growing industries in the world and China is one of the key players. ${ }^{8}$ Driven by high population numbers and the rapid development in information and communication industries in the country, China has become the leading producer and consumer of computers in the world and the quantity of electronics industry output has been increasing at an average rate of over 20\% per annum in the past decade. The most reliable data are available from the official Chinese government press agency Xinhua, which is the biggest centre for collecting information in China. These show that consumption of computers and mobile phones has rapidly increased over the years: it was estimated that there were about 20 million computers and 190 million mobile phones in use in 2004 in China. ${ }^{9}$ Table 1 shows the estimated quantities of five main electronic products currently in use and annual waste from them. ${ }^{9,10}$ Xinhua also presents estimates from the State

\begin{tabular}{|lcc|}
\hline Category & $\begin{array}{c}\text { Electronic products } \\
\text { in use }\left(\times 10^{6}\right)\end{array}$ & $\begin{array}{c}\text { Obsolete electronic } \\
\text { products }\left(\times 10^{6}\right)\end{array}$ \\
\hline TV sets & 350 & 5 \\
Refrigerators & 130 & 4 \\
Washing machines & 170 & 5 \\
Computers & 20 & 5 \\
Mobile phones & 190 & 30 \\
&
\end{tabular}

Environmental Protection Agency (SEPA), that about 1110000 tons of electronic products become obsolete annually in China and constitute about $1 \%$ of municipal solid waste. ${ }^{10}$ Since renovation of computers and mobile phones is much faster than any other electronic products, obsolete computers and mobile phones will grow more rapidly and become the most important part of e-waste in China.

Figure 1 shows the stream of e-waste in China. Obsolete computers and other electronic equipment in China come from individuals, small businesses, large-scale corporations, educational institutions, government and original equipment manufacturers. However, the detailed data describing the relative contribution which each source made to the overall e-waste stream are not available. Domestic e-waste is mainly collected by individual brokers or street hawkers and then resold. Some domestic e-waste is resold to low-income customers, such as migrant workers in big cities and university students, resold to customers in rural areas, donated or directly reused. Some of it may temporarily be stored, which becomes the waste stream after a couple of years. Joining the stream is the illegally imported e-waste. Investigations carried out in 2002 showed that millions of pounds of e-waste from obsolete computers and TVs were being generated in the US each year and huge amounts (an estimated 50-80\% collected for recycling) were being exported to Asia's developing countries, 90\% of which were exported to China. ${ }^{5}$ Other sources of illegally imported e-waste are Japan, Canada, South Korea and Europe., ${ }^{5,11}$

After it has been acquired, e-waste is then dismantled, sorted and conveyed onwards. Useable components will be sold on the second-hand market for reuse in repairs or in manufacturing new products. Valuable materials will be sold to the regenerative resource market, which eventually enters the new production systems. The useless materials and components will be disposed

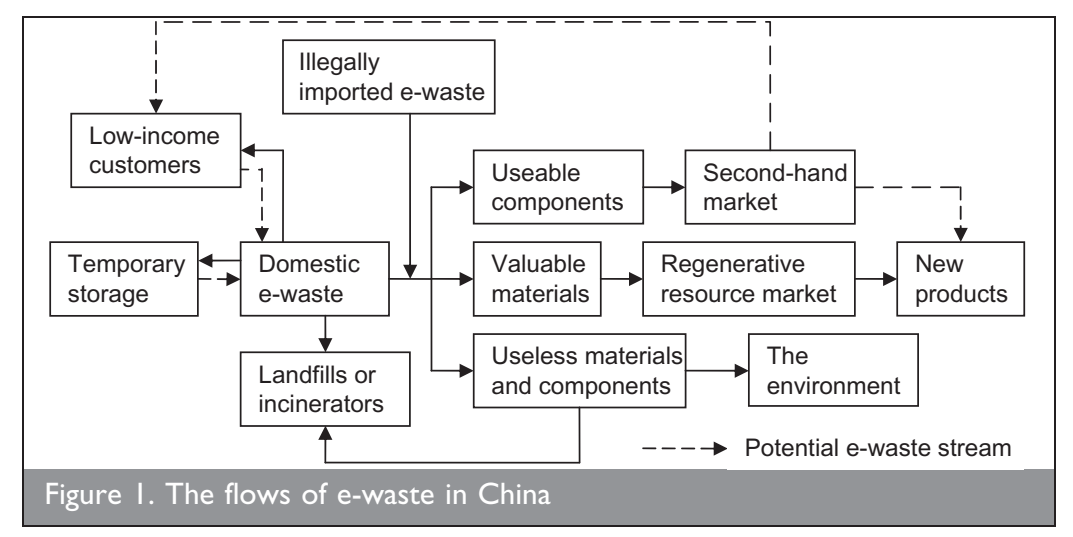


of in landfills or incinerators. If e-waste was properly recycled, a lot of valuable materials could be reused in new products, in line with the basic pattern of the circular economy. However, this is not often the case in China, due to inadequate e-waste management systems. Instead, only small amounts of e-waste enter the recycle chain and the rest is indiscriminately discarded into the environment, resulting in serious pollution.

\section{ENVIRONMENTAL AND HEALTH PROBLEMS CAUSED BY E-WASTE}

Improper disposal methods and poor recycling processes of ewaste practised in China have had a serious negative impact on the people involved and the environment. For instance, a report by the civil society in 2002 exposed serious environmental pollution and health issues in the Guiyu area, one of the e-waste dismantling centres in the Guangdong Province of China. ${ }^{5}$ This report showed that simple and even primitive methods were being applied to dispose of e-waste, which are extremely polluting and harmful to the health of workers and residents. These methods included manual and unprotected removal of printer cartridge toner, open incineration of wires to recover copper, de-soldering of printed wiring boards and the use of open acid baths to retrieve precious metals from chips and other electronic components. The groundwater of Guiyu was so polluted that the drinking water has to be delivered from the nearby towns. It was found that a water sample collected from the river near e-waste open burning sites contained $1.9 \mathrm{mg} / \mathrm{l}$ lead, which is 190 times over the World Health Organisation (WHO) lead threshold. ${ }^{5}$

In other pollutant-monitoring research, carried out by Hong Kong Baptist University within the Guiyu area, the results indicated that the concentration of total polycyclic aromatic hydrocarbons (PAHs) was fairly high with the highest being $593 \mu \mathrm{g} / \mathrm{kg}$ in the sample sediment from the waste printer rollers dump site. ${ }^{12}$ Sediment found from the main water resource in this area was contaminated by PCBs, with a concentration of $743 \mu \mathrm{g} / \mathrm{kg}$ which exceeds the Canadian environmental quality guidelines probable effect level of $277 \mu \mathrm{g} / \mathrm{kg}$ by a factor of $2 \cdot 7$. The concentration of polybrominated diphenyl ethers (PBDEs) in soils near direct dumping sites was found to be 1140-2196 ng/g, between 10 and 60 times higher than those reported in other contaminated locations in the world. ${ }^{12}$

A report by the Shantou Medical University Hospital details the social and health effects of the informal e-waste dismantling and recycling system in Guiyu which involves approximately $80 \%$ of the local families. The high incidence of skin damage, headaches, vertigo, nausea, chronic gastritis and gastric and duodenal ulcers was found in the population of the Guiyu area. ${ }^{13}$ As well as local residents, many recycling and treatment processes were carried out by poorly paid migrant workers from outside this area, who suffered from many cases of respiratory tract infection and kidney stones. The incidence of these health problems was higher among migrant workers in this industry than in others. ${ }^{14,15}$ Another survey among 165 children aged between 1 and 6 at four Guiyu kindergartens found that $82 \%$ of the Guiyu children had blood lead levels of more than $100 \mu \mathrm{g} / \mathrm{l}$, which will affect young children's IQ and the development of the central nervous system. ${ }^{16}$
In 2003, China Central Television exposed similar poor work methods and environmental problems in another e-waste dismantling centre in Wenling City, Taizhou region in Zhejiang Province. ${ }^{11}$ This centre, similar to the Guiyu area in that it is owned by small-scale entrepreneurs or unlicensed families, was dismantling e-waste to extract precious metals and to sell obsolete electronic products to second-hand markets. The environmental management department and other relevant institutions duly responded to the media's exposure of these e-waste-related problems. In Wenling City, the local government passed a bylaw banning the processing of e-waste by nonregistered small-scale entrepreneurs. Although a task force was immediately set up to identify and dismantle illegal e-waste dismantling work-sheds, they still existed in 2004. ${ }^{17}$ Despite all these measures, another investigation undertaken in Guiyu in 2005 still showed that most stages in the processing of electrical and electronic wastes had the potential to release substantial quantities of toxic heavy metals and organic compounds to the workplace environment as well as to surrounding soils and water courses. $^{18}$

Apart from the cases described above, environmental pollution issues caused by e-waste have continuously been highlighted in other areas of China. Despite these well-publicised exposures, the number of small-scale e-waste dismantling work-sheds is on the increase: the small-scale entrepreneurs are motivated by high profits from the trade, even though it is at a high cost both to health and to the environment. In order to manage and alleviate these negative impacts, there is a need to have government policies, regulations and institutions in place to support environmentally sound recycling and disposal of e-waste in China.

\section{CURRENT LEGISLATION FRAMEWORK FOR E-WASTE MANAGEMENT IN CHINA}

The high magnitude of e-waste generation in China, coupled with its negative environmental and health impact, calls for clear policies, regulations, systems and institutions for effective management and control. In response to these developments, the Chinese government and its subsidiary institutions have developed a legislative framework that has paved the way for the establishment of regulatory systems, procedures and institutions. SEPA is in charge of the general solid waste management aspects and the importation of all kinds of wastes. SEPA coordinates solid waste management activities carried out by environmental protection agencies at the various hierarchical levels, that is, at the township, county, city and provincial levels.

Three other national level departments and institutions work with SEPA for effective management and regulation of e-waste. These are (a) National Development and Reform Commission of China (NDRC); (b) Ministry of Information Industry (MII); and (c) General Administration of Customs (CGA). SEPA, NDRC and MII have worked together to develop laws and regulations for effective e-waste management, which may be categorised as (a) those for legislating against health hazards and environmental pollution; and (b) those for legislating against illegal importation of e-waste.

4.I. Regulation on prevention of pollution from e-waste Table 2 lists the main relevant laws and regulations for effective e-waste management in China. Several national legislations 


\begin{tabular}{|c|c|c|}
\hline Law/regulation & Effective date & Issuing authority \\
\hline Environmental Protection Law of the PR China & December 1989 & $\begin{array}{l}\text { National People's Congress Standing } \\
\text { Committee }\end{array}$ \\
\hline $\begin{array}{l}\text { Law of the PR China on Prevention of Environmental } \\
\text { Pollution Caused by Solid Waste }\end{array}$ & $\begin{array}{l}\text { April } 1996 \text { (Second version } \\
\text { with effect from April 2005) }\end{array}$ & $\begin{array}{l}\text { National People's Congress Standing } \\
\text { Committee }\end{array}$ \\
\hline $\begin{array}{l}\text { Announcement on reinforcing the environmental } \\
\text { management of the waste of electrical and electronic } \\
\text { equipment }\end{array}$ & August 2003 & $\begin{array}{l}\text { The State Environment Protection } \\
\text { Administration (SEPA) }\end{array}$ \\
\hline $\begin{array}{l}\text { Ordinance on the management of waste household } \\
\text { electrical and electronic products recycling and disposal }\end{array}$ & $\begin{array}{l}\text { Draft released for comments } \\
\text { in September } 2004\end{array}$ & $\begin{array}{l}\text { Development and Reform Commission } \\
\text { (NDRC) }\end{array}$ \\
\hline $\begin{array}{l}\text { Management methods on pollution prevention in } \\
\text { electronic industry }\end{array}$ & July 2005 & Ministry of Information Industry (MII) \\
\hline $\begin{array}{l}\text { Management methods for the prevention of pollution from } \\
\text { waste electrical and electronic products }\end{array}$ & $\begin{array}{l}\text { Draft released for comments } \\
\text { in September } 2005\end{array}$ & $\begin{array}{l}\text { The State Environment Protection } \\
\text { Administration (SEPA) }\end{array}$ \\
\hline
\end{tabular}

which are built on and strengthen the earlier regulations have been drafted by SEPA, NDRC and MII respectively in response to the escalating e-waste problems in China. The Environmental Protection Law of Peoples' Republic (PR) of China (1989) is the basic legislation on waste management (inclusive of e-waste) in China. The special articles on prevention of environmental pollution by e-waste were for the first time integrated into the already existing Law of the PR of China on Prevention of Environmental Pollution Caused by Solid Waste in April 2005. ${ }^{19}$

The regulation described by the "Announcement on reinforcing the environmental management of the waste of electrical and electronic equipment', published by SEPA in August 2003, is the earliest national regulation specifically to tackle e-waste management. Furthermore, this regulation was introduced in direct response to the e-waste management problems in the Guangdong and Zhejiang provinces, as exposed by the national media and international environmental NGOs. ${ }^{11}$

\subsection{Regulations to control importation of e-waste}

The Basel convention on the control of the trans-boundary movement of hazardous waste and their disposal was adopted in 1989 and entered into force in 1992. China ratified this convention in March $2000 .^{20}$ In 1995, the state council issued a circular on the strict control of transference of foreign waste to China which provides that the import of foreign waste shall be administered in two categories: (a) waste that is forbidden to be imported; and (b) waste that may be used as a raw material but the import of which shall be under strict control. ${ }^{21}$ The law on prevention of environmental pollution caused by solid waste that came into effect in 1996 specifically forbade dumping, piling or disposing of solid waste from outside China and the import of solid waste which could not be used as a raw material. ${ }^{14}$ The list of solid waste which may be imported for use as raw materials shall be stipulated, adjusted and announced by the administrative department in charge of environmental protection, together with the department in charge of foreign trade and economic cooperation under the State Council. ${ }^{21}$

The 'Notification on import of the seventh category of wastes', which came into effect in April 2000, categorised abandoned e-waste that would not be accepted for importation to China. These included computers, monitors, CRTs, copiers, microwave ovens, air conditioners, video cameras, electric cooking devices, rice cookers, telephones (except for pay-phones), video games (except for processing for re-export), televisions and refrigerators. ${ }^{5,22}$ On the international scene, China ratified the Basel ban amendment in 2000, which effectively prohibited all exports of hazardous waste from member states of the Organization for Economic CoOperation and Development (OECD), the European Union (EU) and Liechtenstein to developing countries including China. This convention came into force in 2002. ${ }^{23}$ Furthermore, in July 2002, SEPA and the customs administration issued a new list of wastes that were banned for import to China. ${ }^{24}$ The 'Fifth list of prohibited goods for import' includes automatic data processing machines and units thereof; laser and ink-jet printers, input or output units for other automatic data processing machines and printed circuits.

\section{KEY PROBLEMS AND CHALLENGES IN E-WASTE MANAGEMENT IN CHINA}

The e-waste industry in China is developing rapidly, and government institutions are overstretched quickly to set up structures and systems to mitigate against the negative health and environmental impacts thereof. Based on the interviews with the key informants and fieldwork observations of the case study, the key problems and challenges in e-waste management in China were found.

The current national laws and regulations are inadequate, which in turn limits the enactment of the relevant byelaws at lower levels of government. Many of the existing regulations were not developed through a systematic, experimental and participatory approach, and they have therefore been found to be inadequate in several aspects. Furthermore, there are inadequate subsidiary laws in the form of statutory instruments and standards to support the enforcement of the main laws and regulations. For example, there are no subsidiary regulations to control and inspect the second-hand market for obsolete electronic products and the regenerative resource market, which are the two important factors in controlling the downstream flow of e-waste. The existing licensing system and qualification standards are too deficient to (a) guarantee the quality of second-hand electronic products and (b) screen the recycling and disposal enterprises. Furthermore, e-waste is defined differently or sometimes in a contradictory manner in laws/ regulations issued by various departments, which may lead to some small-scale e-waste entrepreneurs to obtain exemptions from the e-waste management laws/regulations.

Currently, almost all e-waste is recovered by individual brokers or retailers and then resold to small-scale dismantling factories or unlicensed family work-sheds which use environmentally 
unsound recycling methods. Most consumers will not pay for the recycling of e-waste but resell obsolete electronic products to individual brokers or retailers. If the government or other professional recycling companies want to recover the e-waste, they have to buy it from these brokers or retailers, which increases the disposal cost of e-waste. Companies involved in recycling and disposal of e-waste require substantial resources if they have to adopt environmentally sound processes. Not much support has been forthcoming from the government, and so these companies meet difficulties in achieving viable profits from the business. As a result, brokers, retailers and small-scale e-waste dismantling factories or unlicensed family work-sheds, who usually use crude processes, are currently the main dealers in e-waste recycling and disposal. It is therefore important that a holistic enabling environment be put in place for the regulatory regime to be effective.

At the moment, individual e-waste dealers who sell parts of obsolete electronic products to low-income customers for re-use or recycling are not regulated by government institutions. Such transactions provide opportunities for unscrupulous private brokers or retailers to sell obsolete electronic products which may already have reached their maximal lifespan. These expired products may be dangerous to the local artisans and users. Some brokers or retailers dismantle obsolete electronic products to obtain useful components for reselling. In some cases, components from older brands are installed into newer products and marketed as brand new to unsuspecting customers. Most consumers have inadequate technical capacity and may not realise the health hazards and serious environmental consequences caused by some types of e-waste.

Officially, the Chinese government permits limited types of imported wastes such as steel and paper. However, components of e-waste are usually mixed into legitimately imported wastes. Cheaper labour, lower recycle/disposal costs and inadequate national environmental standards and regulations in China attract international firms from industrialised countries to export e-waste to China. At the same time, the domestic demand for recycled materials and the higher economic profits accruing from the illegal import of e-waste attract the Chinese small-scale e-waste recycling firms and individuals to deal in the illicit importation. There is need, therefore, for the Chinese border agencies to improve their monitoring quality.

In 2003 the EU Parliament issued two directives that will significantly affect electronic industries in China: one on waste from electrical and electronic equipment (WEEE) and the other on restriction on the use of certain hazardous substances in electrical and electronic equipment (ROHS). ${ }^{25,26}$ When electronic products are exported to European countries, the producers are required to pay for the costs pertaining to recovery and recycling of e-waste. These costs are computed according to the existing labour costs in Europe, which are much higher than those in China. These anticipated recycling costs will invariably increase the overall production cost of electronic products and force some local Chinese electronic producers to bow out of the competitive markets. On the other hand, if the electronic products are manufactured at lower costs such that they do not conform to the EU environmental protection standards, they will not be granted access to the markets of the industrialised countries. These EU directives are therefore perceived to be a green trade barrier to electronic products manufactured in China. ${ }^{27}$ In order to remain competitive in the electronic industry on the global market, China needs to develop relevant policies, regulations and institutions for effective e-waste management and be able effectively to synchronise with international trends.

\section{OPPORTUNITIES FOR E-WASTE RECYCLING}

Good solid waste management practice often leads to economic benefits. Although e-waste is hazardous, if recycled properly some or all of its components may be used to replace raw materials and components required in the growing electronic industry and other manufacturing industries. Since China is a resource-poor country, e-waste recycling and disposal can play a role in the comprehensive utilisation of resources. Presently, the unregulated recycling and disposal process of e-waste utilises backward technologies, and can only recover the most precious and easily extracted materials such as gold plating, copper wiring and lead solder. Other valuable materials, such as platinum, cadmium and barium are discarded, which is not only wasteful but also extremely polluting to the environment. Some materials in e-waste actually have a high economic value and it is important to carry out proper recycling procedures, from both national economic and sustainable development perspectives.

The recovery system is a key issue in the recycling system and for formulating strategies for integrated e-waste management. The effectiveness of the recovery system will invariably affect the downstream flow of e-waste. The current e-waste recovery system, which is mainly composed of individual brokers, retailers, smallscale e-waste dismantling factories or unlicensed family worksheds, is adapted to the social and communal structures in China and may not be easily eradicated. Instead, it may be more feasible to develop regulatory structures that not only take into account the existing social/communal structures, but encourage participation of all the key stakeholders. Additionally, in China the rate of economic development is area-specific: household income and consumption vary from one location to another. Hence, if the market is well regulated, electronic products which have been discarded by higher-income consumers can satisfy the needs of the low-income households at affordable prices, and contribute to the national economy.

The newly enacted EU regulations on e-waste regulations may, on the surface, seem to be hurting the Chinese electronic industry. However, these regulations will motivate Chinese producers to improve their product design and processes by adopting environmentally friendly methods of work. To this end, the Chinese government has already responded by enacting corresponding regulations to comply with international environmental and technical regulations or standards, which is a positive step to improve e-waste management. For instance, the NDRC commissioned a pilot research project in 2003 with the main objective of researching the reuse of obsolete electronic appliances. Qingdao City in Shandong Province and Zhejiang Province were commissioned as a demonstration city and province for cutting-edge technological methods of promoting environmentally and economically sustainable e-waste management. ${ }^{28}$ This development may be a starting point for the Chinese government in working towards providing a more enabling environment in terms of capacity building, financial and technical support to the Chinese entrepreneurs. 
Since March 2008, SEPA has been upgraded to the Ministry of Environmental Protection (MEP), which aims to strengthen the environmental protection in China. In the report issued by MEP in 2007, pollution control in China has shifted from passive response into active prevention. This is a sound step towards the historic transformations in environmental protection. ${ }^{29}$ It is an opportunity for government to investigate the pollution caused by e-waste, reduce the hazards in e-waste from production design, strengthen the control of e-waste import and improve the effective management of e-waste in China.

\section{CONCLUSION}

China, the fastest growing developing country in the world, cannot escape from environmental pollution from e-waste and its harmful effects on health. With the accelerated development of the electronics industry in China, the associated high accumulation of e-waste will become a heavy burden on solid waste management systems in China. Hence, the Chinese government needs to strengthen regulatory systems to ensure that the huge economic benefits from the e-waste recycling industry are not overshadowed by the negative impact on health and on the environment. There is a need to devise strategies effectively to manage e-waste. Such strategies need a good enabling environment in the form of conducive legislative and institutional frameworks.

E-waste is becoming a serious issue in China, driven by the rapidly increasing quantities as well as its toxic nature and the economic value of the recycled substances. The government of China has already responded by developing appropriate policies, regulations, systems and institutions. The existing legislative and regulatory framework should be strengthened in order to

(a) effectively control environmental pollution caused by ewaste

(b) regulate the second-hand market of electronic products

(c) comprehensively utilise valuable materials in e-waste

(d) develop regulated recovery system of e-waste

(e) regulate e-waste import from industrialised countries

(f) harmonise internal control systems with international legislative frameworks and institutions for effective competition on the international market.

The NDRC's pilot research project in e-waste management is a step in the right direction. More resources should be invested for research and development of advanced technology for recycling and disposal of e-waste and for supporting the industrialisation of e-waste recovery and disposal in an economically and environmentally sustainable manner. Furthermore, the Chinese government needs to provide an enabling environment for the implementation of the scientific concept of development, take a new route to industrialisation, develop a circular economy, construct a conservation-minded society and implement a sustainable development strategy.

\section{ACKNOWLEDGEMENTS}

The authors are grateful to the stakeholders in China who took part in the research as informants. Special thanks go to Zhou Yugang from Guohuan Environmental Engineering Design and Research Institution of Tsinghua University, Beijing, for assistance with data collection.

\section{REFERENCES}

1. ARENSMAN R. Ready for recycling? Electronic Business, the Management Magazine for the Electronics Industry, 2000, 26, No. 12, November.

2. Widmer R., KrapF O.H., Khetriwal S.D., Schnellmann M. and BöNI H. Global perspectives on e-waste. Environmental Impact Assessment Review, 2005, 25, No. 5, 436-458.

3. FISHBEIN B. K. Waste in the Wireless World: The Challenge of Cell Phones. INFORM, Inc, May 2002, 61.

4. Toxics LinK. Scrapping the Hi-tech Myth: Computer Waste in India, February 2003. See http://www.toxicslink.org/pub-view. php?pubnum $=37$ for further details.

5. The Basel Action Network and Silicon Valley Toxics Coalition. Exporting Harm: the High-tech Trashing of Asia, February 2002. See www.ban.org/E-waste/technotrashfinalcomp.pdf for further details.

6. Beary H. Bangalore Faces E-waste Hazards, No. 6, 31 January 2005. See http://news.bbc.co.uk/2/hi/south_asia/ 4222521.stm for further details.

7. Ye J. E-waste Management in Developing Countries through Legislation and Regulations: a Case Study of China. PhD thesis, Loughborough University, UK, 2008.

8. ZHou Z. F. Analysis of the problems in e-waste disposal. Electronic Manufacturer. February 2004 (in Chinese).

9. Zhang J. C. and Zou L. New Pressures Exerted by E-waste on Environment, June 2004 (in Chinese). See http://news. xinhuanet.com/newscenter/2004-06/20/content_1535612. htm for further details.

10. Xinhua News Agency. 1,110,000 Tons of Electronic Waste Produced Every Year in China, 23rd September 2005 (in Chinese). See http://news.xinhuanet.com/mrdx/2005-09/23/ content_3531892.htm for further details.

11. LAI Y. A survey report on the electric wastes in Taizhou City. World Environment, March, 2004, 58-59 (in Chinese).

12. Leung A., CAi Z. W. and Wong M. H. Environmental contamination from e-waste recycling as Guiyu, Southeast China. Proceedings of the $3 r d$ Workshop on Material Cycles and Waste Management in Asia, Tokyo, 2004, pp. 73-84.

13. Qiu B., Peng L., Xu X., Lin X., Hong J. and Huo X. Medical investigation of e-waste dismanufacturing industry in Guiyu town. International Conference on Electronic Waste and Extended Producer Responsibility in China, Beijing, 2004, pp. 79-83.

14. Anthropology Department OF Zhongshan University. A Survey of the Anthropologic Aspects of E-waste Processing in Guiyu, China, 2003 (in Chinese).

15. Hicks C., Dietmar R. and Eugster M. The recycling and disposal of electrical and electronic waste in Chinalegislative and market responses. Environmental Impact Assessment Review, 2005, 25, No. 5, 459-471.

16. Peng L., Huo X., Xu X. J., Zheng Y. and Qiu B. Effects of electronic waste recycling and disposing contamination on children's blood lead level. Journal of Shantou University Medical College, 2005, 18, No. xx, 48-50 (in Chinese).

17. LAI Y. Research report on recycling of electronic waste in Taizhou, Zhejiang. Chinese Journal of Resource Comprehensive Utilization, 2004, No. 6, 7-8 (in Chinese).

18. BRigden K., LabunsKa I., SAntillo D., and Allsopp M. Recycling of Electronic Wastes in China and India: Workplace and Environmental Contamination, 2005. See http://www. greenpeace.org/raw/content/china/en/press/reports/ recycling-of-electronic-wastes.pdf for further details. 
19. SEPA. Law of the People's Republic of China on the Prevention and Control of Environmental Pollution by Solid Waste, 2004 (revised version in Chinese). See http://www. zhb.gov.cn/law/law/200412/t20041229_65299.htm for further details.

20. LI Y.L. Information Industry Encountered "Rubbish Economy"?, 2004 (in Chinese). See http://www.dtro.com.cn/ landfill/ArticleShow.asp?ArticleID=622 for further details.

21. SEPA. Urgent Circular on the Strict Control on the Transfer of Foreign Waste to China by the General Office of the State Council, 1995 (in Chinese). See http://www.zhb.gov.cn/law/ fg/gwyw/199511/t19951107_85216.htm for further details.

22. Lin F. C. and WANG Y. Study on prediction of amount of obsolete computers in China and countermeasures.

Shanghai Environmental Science, 2003, 22, No. 7, 479-482, 494 (in Chinese).

23. United Nations Environmental Program (UNEP). The Basel Convention at a Glance..., 2007. See http://www.basel.int/ convention/bc_glance.pdf for further details.

24. SEPA. New List of Wastes China has banned for Import, 2002 (in Chinese). See http://www.zhb.gov.cn/cont/gtfw/200607/ t20060726_91344.htm for further details.

25. European Parliament and Council Of The European Union. Directive 2002/96/EC of the European Union and of the
Council of 27 January 2003 on waste electrical and electronic equipment (WEEE). Official Journal of the European Communities, 2003, 24-38.

26. European Parliament and Council Of The EuRopean Union. Directive 2002/95/EC of the European Union and of the Council of 27 January 2003 on the restriction of the use of certain hazardous substances in electrical and electronic equipment. Official Journal of the European Communities, 2003, 19-23.

27. XIE R.S. and CAI Y. Analyzing the impact of EU green trade barriers on household electronic product manufactures. South China Economy, 2004, 1, No. 1, 78-80 (in Chinese).

28. National Development and Reform Commission (NDRC). Ordinance on the Management of Waste Household Electrical and Electronic Products Recycling and Disposal, 2004 (drafted for comment in Chinese). See http://www.sdpc.gov. cn/yjzq/default.htm for further details.

29. Ministry of EnVironmental Protection (MEP). The State of the Environment of China 2007 - Pollution Prevention and Control Shifted from Passive Response into Active Prevention, 2008. See http://english.sepa.gov.cn/ News_service/news_release/200806/t20080613_123910.htm for further details.

\section{What do you think?}

To comment on this paper, please email up to 500 words to the editor at journals@ice.org.uk

Proceedings journals rely entirely on contributions sent in by civil engineers and related professionals, academics and students. Papers should be $2000-5000$ words long, with adequate illustrations and references. Please visit www.thomastelford.com/journals for author guidelines and further details. 